\title{
$\mathrm{MLP}$ 에 기반한 감정인식 모델 개발
}

\section{Development of Emotion Recognition Model based on Multi Layer Perceptron}

\author{
이동훈 - 심귀보 \\ Dong-Hoon Lee and Kwee-Bo Sim
}

중앙대학교 전자전기공학부

요 약

본 논문에서, 우리는 뇌파를 이용하여 사용자의 감정을 인식하는 감정인식 모텔을 제안한다. 사용자의 감정을 인식하기 위 해서는 우선 생체 데이터나 감정 데이터를 포함한 뇌파의 정량적인 데이터를 획득하는 방법이 필요하며 다음으로 획득된 뇌파를.통하여 현재 사용자의 감정 상태를 규명하는 패턴인식 기법이 중요한 문제가 된다. 본 논문에서는 뇌파를 통하여 현재 사용자의 감정 상태를 규명하고 인식할 수 있는 패턴인식 기법으로 Multi Layer Perceptron(MLP)을 사용한 패턴인 식 기법을 사용한다. 본 논문에서 제안한 감정인식 모델의 실험을 위하여 특정 공간 내에서 여러 피험자의 감정별 뇌팔ㄹㄹㄹ 측정하고, 측정된 뇌파로 집중도 및 안정도롤 도출하여 유의미한 데이터로 감정 $\mathrm{DB}$ 를 구축한다. 감정별 $\mathrm{DB}$ 를 본 논문에 서 제안한 감정인식 모델로 학습한 후 새로운 사용자의 뇌파로 현재 사용자의 감정을 인식한다. 마지막으로 피험자의 수 와 은닉 노드의 수에 따른 인식률의 변화를 측정함으로서 뇌파를 이용한 감정인식 모델의 성능을 평가한다.

\begin{abstract}
In this paper, we propose sensibility recognition model that recognize user's sensibility using brain waves. Method to acquire quantitative data of brain waves including priority living body data or sensitivity data to recognize user's sensitivity need and pattern recognition techniques to examine closely present user's sensitivity state through next acquired brain waves becomes problem that is important. In this paper, we used pattern recognition techniques to use Multi Layer Perceptron (MLP) that is pattern recognition techniques that recognize user's sensibility state through brain waves. We measures several subject's emotion brain waves in specification space for an experiment of sensibility recognition model's which propose in this paper and we made a emotion DB by the meaning data that made of concentration or stability by the brain waves measured. The model recognizes new user's sensibility by the user's brain waves after study by sensibility recognition model which propose in this paper to emotion DB. Finally, we estimates the performance of sensibility recognition model which used brain waves as that measure the change of recognition rate by the number of subjects and a number of hidden nodes.
\end{abstract}

Key words : Multi Layer Perceptron, Sensibility Recognition, Sensibility Recognition Model, Biofeedback

\section{1. 서 론}

인간의 뇌파가 가지는 모호성과 복잡성에 대한 정량적인 데이터가 획득 된다면 다양한 서비스의 공급이 가능할 것이 다. 뇌파를 이용하여 질병의 진단 및 정신질환의 조기 발견 이 가능하고 현재 감정에 따른 다양한 서비스의 공급이 가능 할 것이다[1-3]. 때문에 생체신호를 측정하고 이에 대한 데 이터베이스를 구축하고자 다각도의 연구가 진행 중이다.

사용자의 감정을 측정하는 방법은 사용자에 대한 주관적 평가와 생체 신호 측정 장비를 사용한 신호 분석 방법을 들 수 있다[4-5]. 여기서 생체신호란 뇌파와 심전도, 근전도를 총칭하는 말로 이 생체 신호의 분류 및 인식에 대한 연구는

접수일자 : 2006년 4월 13일

완료일자 : 2006년 6월 2일

본 연구는 산업자원부의 뇌신경정보학연구사업의 "뇌정 보처리에 기반 한 감각정보 융합 및 인간행위 모델 개 발'의 연구비 지원으로 수행되었습니다. 연구비 지원에 감사드립니다.
곧 사용자에 대한 서비스 공급의 질적 향상을 의미한다. 본 논문에서는 여러 피험자의 감정에 따른 생체신호를 측 정하고 각 감정별 피험자들의 공통된 특징점을 추출 한다. 추출된 신호를 감정인식 모델을 사용하여 학습 한 후 새 사 용자의 생체 신호를 입력 받아 사용자의 현재 감정 상태를 인식 할 수 있는 감정인식 모델을 제안한다.

본 논문의 구성은 다음과 같다. 2장에서는 생체신호의 획 득을 위해 성인남녀 25 명을 대상으로 각 피험자별 감정에 따 른 생체 데이터를 획득하고 정량화 한 실험에 관한 내용을 정리하고, 3 장에서는 2 장에서 획득한 생체신호를 학습하고 새로운 피험자의 뇌파를 인식하는 인식모델에 관한 내용을 다룬다. 4장에서는 2장에서 획득한 생체신호의 정량화된 데 이터를 3장에서 제안한 학습모델로 학습을 진행한 후 은닉노 드 및 푀험자 수의 변화에 따른 실험 결과에 대해 기술한다. 마지막으로 5장에서 결론 및 향후 과제에 대해 논한다. 


\section{2. 생체신호 획득}

\section{1 실험개요}

뇌의 경우 작동기전이 대부분 밝혀져 있지 않아 특정 상 태에 대한 이론적인 추정이 힘들므로, 직접적인 임상실험과 분석을 통해서만 의미부여 및 해석이 가능하다. 생체신호와 같이 사람을 대상으로 하는 실험인 경우, 개인별 편차가 크 기 때문에 통계 처리 및 일반화를 하기 위해서는 최소 25명 이상의 피험자를 대상으로 실험을 한다. [8] 본 논문에서는 질병이 없는 성인 남성 15 명과 성인 여성 10 명에 대하여 실 험을 실시하였고 감정유발은 컴퓨터 모니터를 사용하여 여러 감정을 유발시키는 사진(IAPS)을 자극으로 제시함으로서 실 행되었다. 이 실험으로 얻고자 하는 결과는 각 감정별 뇌파 의 주퐈수 변화량과 안정지표, 집중도이다. 사용자의 생체 신 호를 획득하기 위한 측정 장비로는 $\mathrm{EEG}$ 측정기 $\mathrm{QEEG} 8$ 와 심전도 측정기 LXC3203(LAXTHA Inc.)을 사용하였다.

intisti
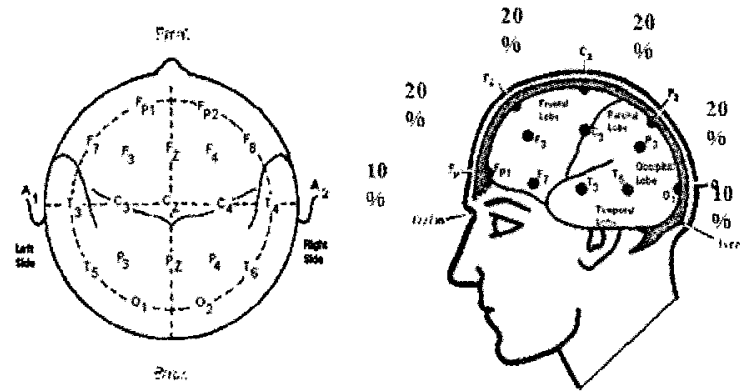

그립 1. 국제 전극배치법 (10/20법)

Fig. 1. 10/20 electrode system

실험은 피험자의 머리표면에 모노폴라 방식으로 측정하였 으며, $10 / 20$-국제 전극배치법에 의해 차례로 측정전극을 부 착하여 실행되었다. 고도의 인지, 감정, 정신적 기능 등을 담 당하는 전두엽 $(\mathrm{Fp} 1, \mathrm{Fp} 2, \mathrm{~F} 3, \mathrm{~F} 4)$ 과 청각영역의 측두엽(T3, $\mathrm{T} 4)$, 시각영역의 후두엽(P3, P4)에 센서를 부착 하였고, 기준 전극은 $\mathrm{A} 1$, 접지 전극은 뒷목에 부착한 후 실험을 진행 하었 다. 그림 1은 $10 / 20$-국제전극배치도를 보여준다.

\section{2 실험환경 및 실험대상}

실험을 위하여 연구실 내의 한 부분을 선정 하였고 피험 자의 편안한 상태를 유지하기 위하여 실내 온도 $(24 \mathrm{C})$, 습도 (44 50\%), 조도 $(150 \sim 200 \mathrm{Lx})$ 를 유지하였다. 정확한 $\mathrm{EEG}$ 신호의 특징을 얻기 위해서는 전극의 위치선택이 매우 중요 함을 알 수 있다. 또한 EEG 신호는 사람에 따라 주변 환경, 개개인의 정신상태, 그리고 시간의 흐름에 따라 같은 정신 상태에 대하여 많은 변동을 가지고 있다. 또한 낯선 환경과 실험 방법에 대한 피험자의 불안한 상태 또한 실험에 많은 영향을 준다. 때문에 실험방식에 대한 거부감을 줄이기 위하 여 푀험자는 실험방식에 대해 일정기간 충분한 연습을 하고 실험 대상은 정신질환이나 몸에 질병을 지니지 않은 건강한 성인남녀 25 명에 대하여 실험을 실시하였다.

\section{3 실험자극}

플로리다 대학 심리학과 Peter Lang 교수가 개발하여 국 제적으로 동용되고 있는 표준화된 감정자극 체계로 일상생활
의 사진 480여장으로 구성된 국제 정서 사진 체계 (International Affective Picture System, IAPS)의 사진 중 감정의 이차원적으로 분류된 8가지 감정(평온, 상쾌, 기쁨, 통쾌, 긴장, 불안, 실망, 허탈)을 자극하는 사진 6 장을 선택하 여 피험자들에게 보여주고 자극에 따른 기본 감정 6가지(기 쁨, 슬픔, 분노, 웃음, 좌절, 놀람)에 대한 생체신호를 측정 하 였다. 그림 2는 실험 장소에서 피험자에게 자극을 제시하고 생체신호를 측정하는 모습을 보여준다.

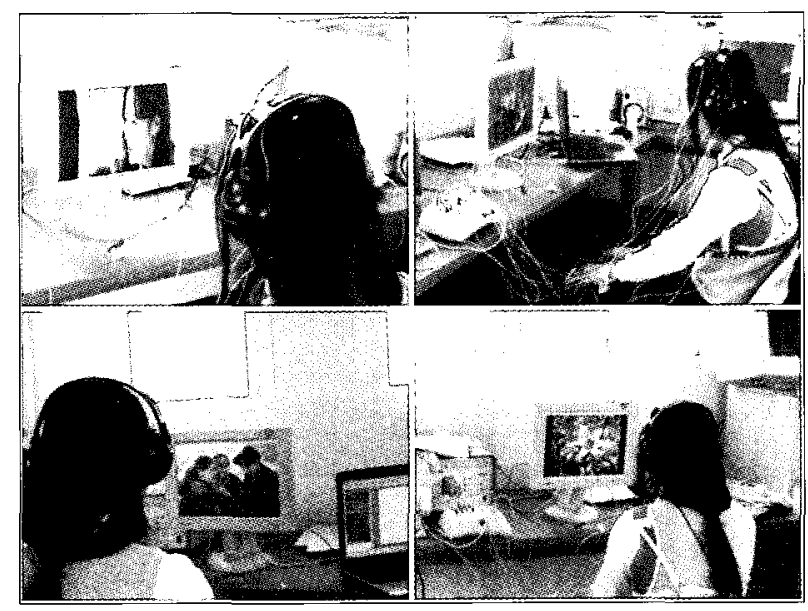

그림 2. 생체신호 측정

Fig. 2. Biosignal measurement

뇌파는 머리표면에서 측정되는 $\mathrm{uV}$ 단위의 미세한 전위신 호이므로 피험자의 눈 움직임, 몸 움직임, 전극선 흔들림, 접총불량, 안면근수축, 주변 진동등에 의해 쉽게 잡파가 혼입 된다. 뇌파 측정시 잡화가 혼입되면 원하는 신호를 측정하는 데 문제가 되므로 실험 중에는 최대한 이런 잡파의 혼입을 방지해야한다. 본 실험에서는 IAPS의 사진으로 감정을 유발 하기 때문에 눈 움직입에 의한 안전도 혼입과 안면 근수축에 의한 근전도 혼입이 가장 큰 문제가 되었다. 눈 움직임에 의 한 안전도 혼입은 피험자가 눈을 굴리거나 눈을 깜박이면 해 당시점에 큰 진폭의 피크가 나타나는데 이는 피험자의 눈 움 직임에 의해 눈 주변에 발생한 안전도(EOG)가 눈 가까운 부 위, 즉 전두엽에 부착된 전극에 혼입되어 들어온 경우이고, 안면 근수축에 의한 근전도 혼입은 피험자가 웃거나 찡그리 는 등의 안면 근육수축을 유발하는 행위를 하면 이때 발생한 근전도(EMG)신호가 뇌파전극에 혼입되는 것을 말한다. 이 러한 문제점을 방지하기 위해 사진 자극을 제시할 때 피험자 는 모니터에 시선을 고정한 후 1분간 눈을 깜박이지 않게 주 의를 주었다. 또한 사진 자극에 대한 외형적 감정표출(웃음 과 같은)을 하지 못하도록 하였다. 본 논문에서는 이와 같은 사항들을 고려한 후 성인남녀 25명에 대한 데이터를 측정 및 분석 하였고 그 결과 그림 2.4절과 같은 감정별 유의미한 생 체신호를 획득할 수 있었다.

\section{4 실험절차 및 실험 결과}

본 논문에서 사용한 실험 방법은 사용자가 작성하는 주관 적 평가지와 측정장비를 사용한 생체측정을 통하여 사용자의 현재 감정 상태의 측정 및 평가를 하였다. 주관적 평가지는 사진을 자극을 받은 피험자가 현재 자신의 감정을 평가지에 있는 6 가지 항목중 한가지를 선택하고 감정상태의 정도를 
상, 중, 하로 표기하는 방법을 사용 하였다. 표 1 은 실험절차 를 보여준다.

표 1. 실험 절차

Table 1. Experiment Procedure

Step 1. 실험 30 분전 설문지 작성 및 실험에 대한 설명

Step 2. 휴식(눈을 감은 상태) 30 초

$\rightarrow$ 휴식 (눈을 뜬 상태) 30 초

$\rightarrow$ 장면 자극 슬라이드 6 장의 자극

제시 및 평가(사진당 10 초 노출)

$\rightarrow$ 휴식(눈감고 30 초, 눈뜨고 30 초)

Step 3. Step 2의 실혐을 6가지 자극

(기뽐, 슬픔, 분노, 웃음, 좌절, 놀람)

에 대해 연속적으로 반복 실험

Step 4. Step 3에 대한 평륜 데이터를 춰득.

* 장면 자극은 10 초 노출 1 분간 자극을 제시하고 총 측정시간은 12 분 30 초로 한다.

뇌파는 진동하는 주파수의 범위에 따라 델타( 8$)$ 파 $(0.2$ $3.99 \mathrm{~Hz})$, 쎄타 $(\theta)$ 파 $(4-7.99 \mathrm{~Hz})$, 알파 $(\alpha)$ 파 $(8 \sim 12.99 \mathrm{~Hz})$, 베타 $(\beta)$ 파 $(13-29.99 \mathrm{~Hz})$, 감마 $(\mathrm{g})$ 파 $(30 \sim 50 \mathrm{~Hz})$ 로 구분하여 측정하고 심전도를 측정 한다. 각 뇌파의 특징으로 델타파는 깊은 수면 시나 신생아의 경우에 두드러지게 나타난다. 만약 건강한 정산인의 겅우엥 델다퐈각 두드러지게 나타난다면 이 는 눈을 깜박이거나 몸을 심하게 움직일 경우가 대부분이다. 쎄타퐈는 정서안정 또는 수면으로 이어지는 과정에서 주로 나타나는 파로 기억력, 창의력, 집중력, 불안해소 등 다양한 상태와 관련되어 있으나 연구자들마다 실험 프로토콜과 피험 자 톡성이 조금씩 달라 아직까지 표준화된 결과는 부족한 실 정이다. 알파파는 긴장이완과 같은 편안한 상태에서 주로 나 타나며, 안정되고 편안한 상태 일수록 진폭이 증가 한다. 베 타파는 의식적인 활동을 할 때 나타나며 특히 불안한 상태나 긴장시, 복잡한 계산처리시에 많이 나타나고 감마파는 정서 적으로 초조한 상태이거나 추리, 판단 등의 고도의 인지 정 보 처리와 관련 깊다고 보고되고 있다[4-5]. 보통 만성피로 나 수면부족 상태에서도 집중수준이 급격히 감소하게 되므 로, 이를 사전에 점검하여 실험 전 충분한 신체적 휴식을 취 할 수 있도록 조치하였다. 그림 3 은 본 실험에서 측정된 각 감정별 뇌파의 주파수 변화량을 보여준다.

각 감정별 주파수는 그림 3에서 High Beta파와 Gamma 퐈의 변화가 가장 두드러진 특징을 보였다. 특히 여성이 남 성보다 감정별 격차가 크다는 점을 알 수 있었다. 다음으로 각 감정별 집중도의 변화량을 식 1 에 의해서 정량화한 모습 을 그림 4에서 보여준다.

집중상태에서 쎄타리듬은 줄어들면서 unfocused attention을 의미하는 SMR리듬 $\left(12^{\sim} 15 \mathrm{~Hz}\right)$ 과 focused attention을 의미하는 $\mathrm{Mid}-\mathrm{Bata}$ 리듬 $\left(16^{\sim} 20 \mathrm{~Hz}\right)$ 이 증가하게 된다. 따라서 집중지표는 다음 수식과 같이 쎄타파에 대한 $\mathrm{SMR}$ 과 $\mathrm{M}-\mathrm{Beta}$ 리듬비율에 의해 정량화 된다.

집중지표 $=$ Power Ratio of $(\mathrm{SMR}+\mathrm{M}-$ Beta $) /$ Theta

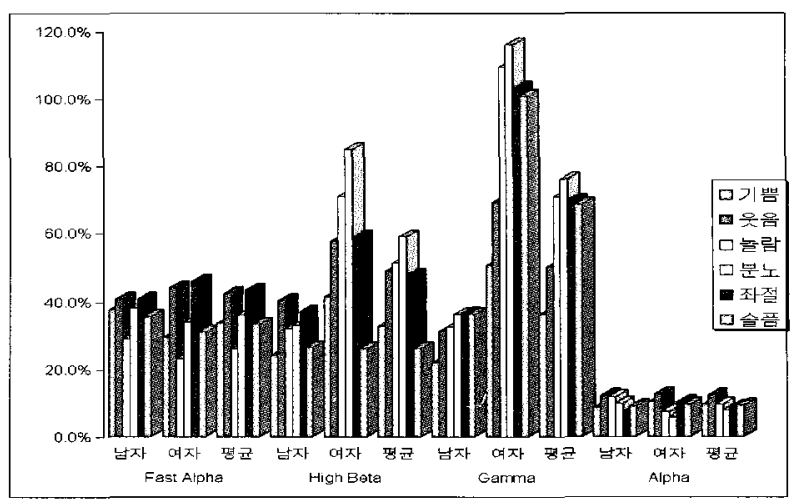

그림 3. 각 감정별 $\mathrm{EEG}$ 주파수 변화량

Fig. 3. variations of EEG frequency about sensibilities

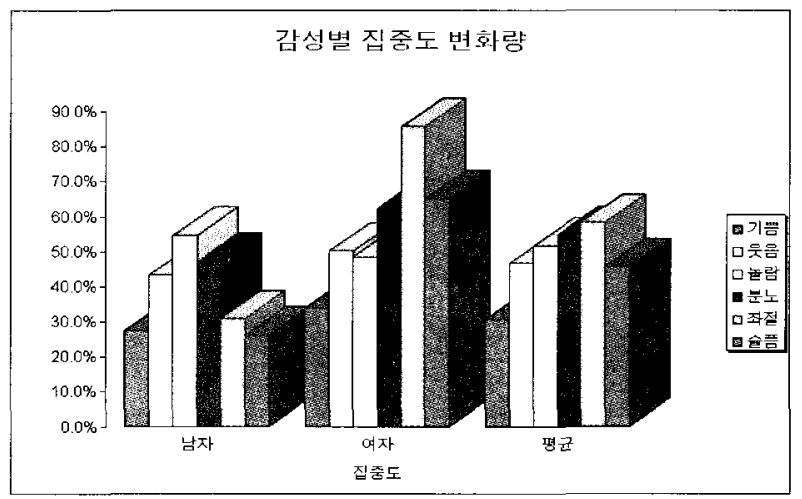

그림 4. 각 감정별 집중도 변화량

Fig. 4. variations of concentration about sensibilities

High-Beta Power에 대한 Alpha Power의 비율인 뇌파의 안정지표는 다음 식 2 로 나타널 수 있다.

안정지표 $=$ Power Ratio of(Alpha/H-Beta)

그림 5 는 식 2 로 정량화된 뇌파의 안정지표를 보여준다. 개 인별 편차는 있겠지만 성별로 분류하여 정량화한 결과 여성의 안정지표가 큰 폭으로 변화하는 것을 확인할 수 있었다.

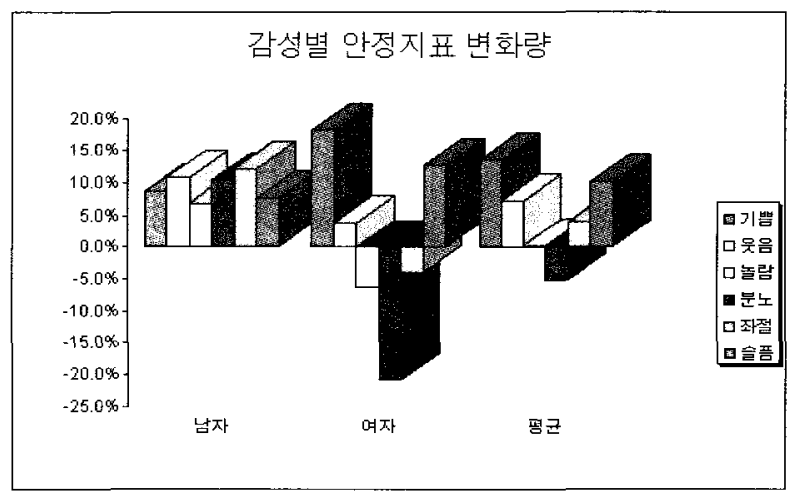

그림 5. 각 감정별 안정지표 변화.

Fig. 5. variations of stability criteria about sensibilities

실험에서 획득한 각 감정별 주퐈수 변화량과 집중도 및 안정지표를 순위선 택법을 이용하여 전처리를 하면 남성 $60 \%$ 
여성 85\%의 상대적으로 높은 수치의 특징점을 찾을 수 있었 다. 표 2는 순위 선택법을 사용하여 각 감정별 편차가 큰 지 표를 순위를 정하고 정해진 순수에 따라 입력 패턴으로 사용 할 값을 할당하는 모습을 보여준다. 표 2의 전처리 과정을 거치면 표 3 과 같은 각 감정별 지포에 대한 할당 값을 얻을 수 있다. 순위 선택법으로 전처리를 한 후 그 결과를 학습 알 고리즘을 이용해 감정을 인식한다.

표 2. 순위선택법을 사용한 정량화데이터.

Table 2. The quantification data using ranking selection.

\begin{tabular}{|c|c|c|c|c|c|c|}
\hline \multirow{2}{*}{ High Beta } & 85 & 71 & 58 & 57 & 41 & 26 \\
\cline { 2 - 7 } & 분노 & 놀람 & 좌절 & 웃음 & 기쁨 & 슬픔 \\
\hline \multirow{2}{*}{ Gamma } & 116 & 109 & 103 & 101 & 69 & 50 \\
\cline { 2 - 7 } & 분노 & 놀람 & 좌절 & 슬픔 & 웃음 & 기쁨 \\
\hline \multirow{2}{*}{ 안정지표 } & 18.2 & 12.8 & 3.8 & -3.9 & -6.2 & -20.8 \\
\cline { 2 - 7 } & 기뽐 & 슬픔 & 웃음 & 좌절 & 놀람 & 분노 \\
\hline \multirow{2}{*}{ 집중도지표 } & 85.6 & 65.1 & 62.4 & 50.1 & 48.4 & 33.9 \\
\cline { 2 - 7 } & 좌절 & 슬픔 & 분노 & 웃음 & 놀람 & 기쁨 \\
\hline 순위 & 1 & 2 & 3 & 4 & 5 & 6 \\
\hline \multirow{2}{*}{ Value } & 1 & 0.8 & 0.6 & 0.4 & 0.2 & 0 \\
\hline
\end{tabular}

표 3. 전처리 후 결과 값

Table 3. The result after preprocessing

\begin{tabular}{|c|c|c|c|c|c|c|}
\hline 감정 & 기뽐 & 슬픔 & 놀람 & 좌절 & 분노 & 웃음 \\
\hline High Beta & 0.2 & 0 & 0.8 & 0.6 & 1 & 0.4 \\
\hline Gamma & 0 & 0.4 & 0.8 & 0.6 & 1 & 0.2 \\
\hline 안정지표 & 1 & 0.8 & 0.2 & 0.4 & 0 & 0.6 \\
\hline 집중도지표 & 0 & 0.8 & 0.2 & 1 & 0.6 & 0.4 \\
\hline
\end{tabular}

\section{3. 학습 모델}

본 논문에서는 생쳬산호에 따른 사용자의 감정을 인식하 기 위해 패턴인식에서 자주 사옹하는 신경망을 이용한 패턴 인식 기법을 사용하였다. 신경망 모델은 MLP(Multi Layer Perceptron)모델을 사용하였고, 학습 알고리즘은 순방향 다 층신경망의 학습에 효과적으로 사용할 수 있는 $\mathrm{BP}$ (Back Propagation)알고리즘을 사용하였다. 그림 6 은 본 논문에서 사용한 학습 모델인 순방향 다층신경망 MLP모델을 보여준 다.

MLP모델은 특징점으로 선택된 High Beta파, Gamma파, 안정지표 및 집중도지표를 입력 받을 수 있는 24개의 입력 노드와 6 개의 감정을 출력할 수 있는 3 개의 출력노드로 구성 하였고, 히든노드는 550 개까지 임의로 변경하면서 결과 값을

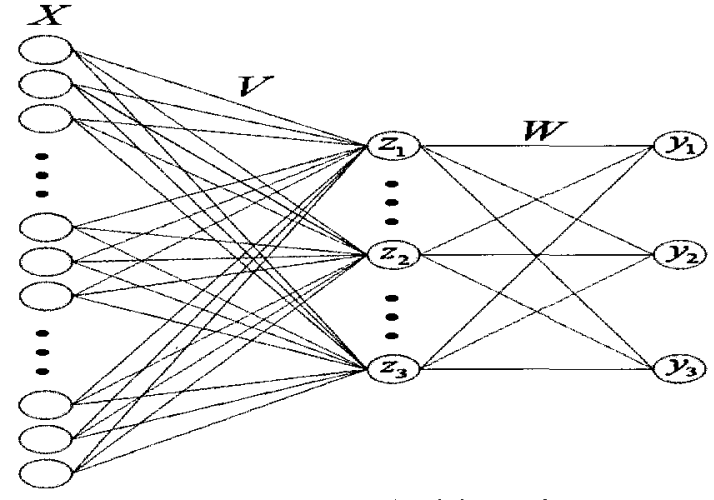

그림 6. 신경망 감정 학습 모델.

Fig. 6. The sensibility learning model used neural network.

측정 하였다. 순방향 다층 신경망의 학습에 효과적으로 사용 할 수 있는 $\mathrm{BP}$ 알고리즘은 출력층의 오차 신호를 역전파 하 여 은닉충과 출력층간의 연결 강도와 입력층과 은닉층간의 연결강도를 변겅하는 학습 방법으로 다양한 분야에 그 응용 범위가 넓다.[8][9] 출력층은 3 개의 노드로 구성하여 2진 값 으로 감정별 신호를 출력한다. 본 논문에서 사용한 $\mathrm{BP}$ 알고 리즘의 주요 설정파라메타는 오차율 0.000001 , 학습율 0.1 , 각 감정별 목표치 $001 \sim 110$, 초기 가중치는 $-0.01 \sim 0.01$ 로 랜 덤하게 설정하였다. 활성화 함수는 단극성 시그모이드함수를 사용하였고, 은닉노드의 개수 및 피험자 수의 변화에 따른 인식률의 차이를 실험하였다. 다음은 $\mathrm{BP}$ 학습알고리즘의 계 산 순서이다. 식 3 은 활성화 함수로 단극성 시그모이드함수 를 사용하는 겅우를 보여준다.

$$
Z=\frac{1}{1+e^{- \text {weighted sum }}}
$$

입력 가중합(weightd sum)으로부터 은넉 노드와 출력 노 드의 시그모이드 함수를 거친 최중출력과 미리 설정된 목표 치를 비교하여 출력층의 오차신호를 구한다. 그 수식은 다음 과 같다.

$$
\delta=(d-o u t) o u t(1-o u t)
$$

출력층의 오차신호로 은닉층에 전파되는 오차신호를 구한 후 은닉층과 출력층간의 연결강도 및 입력층과 은닉층간의 연결강도의 변화랑을 구하고 연결강도의 변화량이 구해지면 다음 학습단계에서 사용 될 연결강도를 구한다. 수식으로 표 현하면 다음과 같다.

$$
\begin{aligned}
& \Delta W=a \delta Z \\
& W_{k+1}=W_{k}+\Delta W
\end{aligned}
$$

여기서 $\mathrm{Z}$ 는 입력패턴 또는 시그모이드 함수를 거친 은닉층 의 출력(식 3)이다. $\mathrm{BP}$ 학습 알고리즘은 기술한 식들에 의해 학습이 이루어지며 설정된 오차율에 도달할 때까지 학습을 진행한다. 실험걸과 야 80 만번의 반복을 거친 후 설정 오차 율에 도달할 수 있었다(Intel Pentium 4, CPU 2.0GHz).

그림 7은 $\mathrm{BP}$ 알고리즘을 적용한 $\mathrm{MLP}$ 모델의 학습 과정 및 인식결과를 확인하고 목표 오차율과 히든노드의 개수를 변경 할 수 있도록 작성한 감정추론 엔진의 모습을 보여준다. 


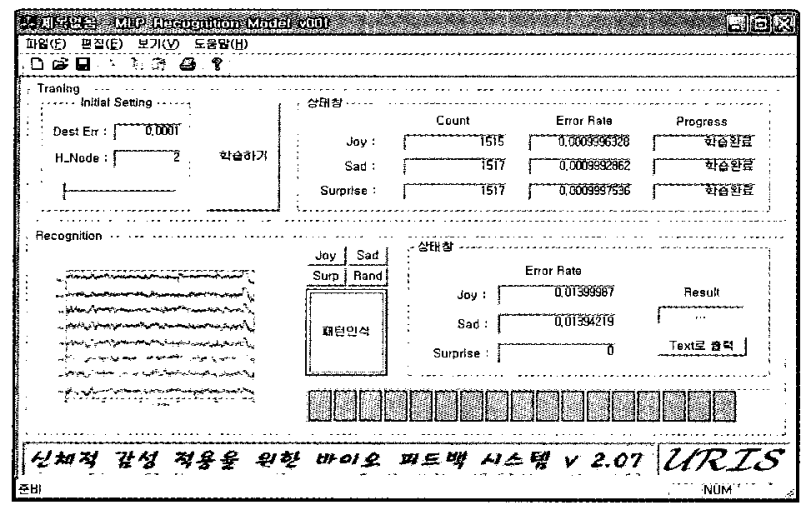

그림 7. 감정인식 엔진

Fig. 7 The sensibility recognition engine

\section{4. 실험 결과}

2 장에서 획득한 정량화된 데이터를 3 장의 학습모델로 학 습 및 인식 실험을 진행 하였다. 실험 결과 은닉 노드의 개수 예 따라 약간의 인식률의 차이는 나지만 실제 감정인식에서 의 인식률에는 큰 영향을 주지 않는 것을 확인할 수 있었다. 그림 8은 은닉노드수의 변화에 따른 인식률의 차이를 보여준 다(피험자 25명).

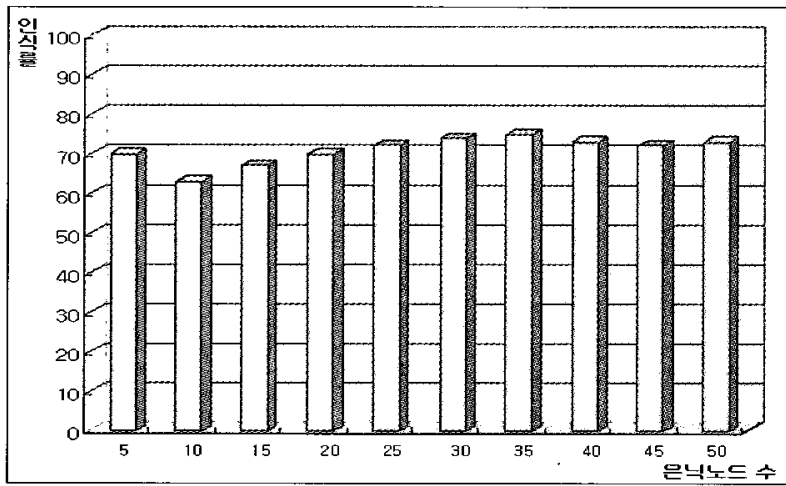

그림 8. 은닉노드의 개수에 따른 인식률 변화.

Fig. 8. The variation of recognition ratio pursuant to a number of hidden nodes.

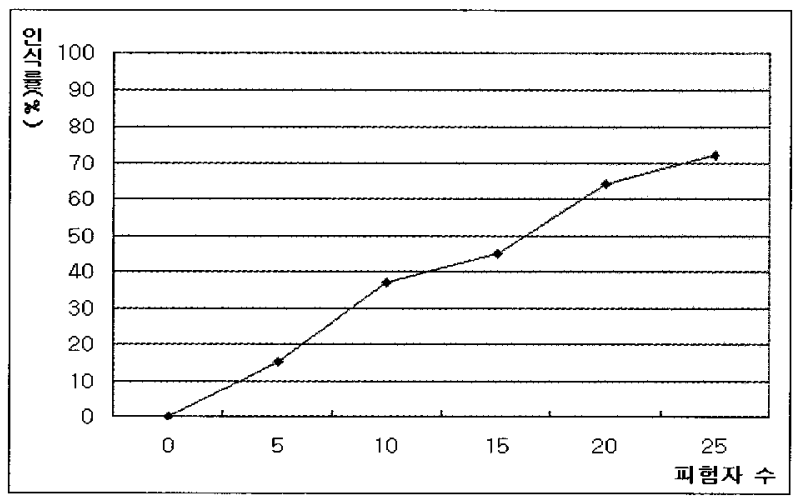

그림 9. 피험자 수에 따른 인식률의 변화

Fig. 9. The variation of recognition ratio pursuant to a number of the subjects
그림 9는 푀험자수의 변화에 따른 인식률의 변화를 보여 준다. 그림 9에서 보이는 것과 같이 피험자의 수가 많을수록 더 좋은 인식 결과를 얻을 수 있었다. 하지만 피험자의 수가 많으면 많을수록 인식률이 급증하는 것은 아니다.

일반적으로 25 - 30명의 피험자를 대상으로 데이터를 획득 하면 통계적 처리가 가능하여 일반화 시킬 수 있기 때문에 25 30명 이상의 피험자를 대상으로 데이터를 획득하여도 인식률이 꾸준히 증가하지는 않는다.

\section{5. 결론 및 향후과제}

본 논문에서는 인간이 느낄 수 있는 감정 중 크게 분류할 수 있는 6개 감정별 뇌퐈를 여러 피험자들을 대상으로 획득 하였다. 또한 획득된 데이터를 안정지표 및 집중도 지표로 정량화 하고 이들 중 특징점을 추출하여 순위 선택법으로 전 처리를 한 후 감정별 $\mathrm{DB}$ 를 구축하였다. 실험으로 얻어진 $\mathrm{DB}$ 는 $\mathrm{MLP}$ 모델에 $\mathrm{BP}$ 학습알고리즘으로 설계한 인식 모델을 사용하여 학습을 진행한 후 은닉노드의 개수 및 피험자의 수 에 따른 인식률을 측정 하였다. 실험결과 은닉노드의 개수가 많아도 인식률이 증가 하지는 않음을 알 수 있었다. 하지만 피험자의 수가 일정 수 이상이 되기 전까지는 피험자의 수가 많을수록 인식률이 증가함을 확인할 수 있었다. 여러 선행 연구에서 지적한바와 같이 생체 데이터의 특성상 개인차가 워낙 심하고 한 사용자 한명에 대한 정보라도 사용자의 순간 적인 기분이나 컨디션에 따라 많은 변수를 내포 하고 있는 것이 사실이다. 본 논둔에서는 처음 30 명의 성인에 대해 실 험 하였지만 평균보다 너무 편차가 크게 벌어지는 피험자 5 명은 제외하고 25 명에 대해서만 $\mathrm{DB}$ 를 구축하였음을 밝힌다. 그 결과 만족할 만한 인식률을 얻을 수 있었다. 본 논문에서 얻어진 결과는 뇌파를 이용하여 사용자에게 다양한 서비스의 제공이 가능하다는 것을 말해주고 있다. 향후 과제로는 인식 률의 항상에 대한 연구가 주류를 이룰 것이라 전망 된다.

\section{참 고 문 헌}

[1] Monastra VJ, Lynn S, Linden M, Lubar JF, Gruzelier J, LaVaque TJ. "Electroencephalographic biofeedback in the treatment of attention deficit/hyperactivity disorder. Appl Psychophysiol Biofeedback. 2005 Jun;30(2):95-114. Review.

[2] Scolnick B. Effects of electroencephalogram biofeedback with Asperger's syndrome. Int J Rehabil Res. 2005 Jun;28(2):159-63.

[3] Weisz N, Moratti S, Meinzer M, Dohrmann K, Elbert T. Tinnitus perception and distress is related to abnormal spontaneous brain activity as measured by magnetoencephalography. PLoS Med. 2005 Jun;2(6):e153. Epub 2005 Jun 28.

[4] 정순철, 민병찬 외, "시각자극에 대한 실시간 및 비 실시간 주관적 평가와 생리반응과의 상관관계," Journal of the Ergonomics Society of Korea, Vol. 18, No.3, pp. 27-39, 1999.

[5] 황민철, 류은경, 김철중, "시각 감정평가를 위한 뇌파 의 민감정에 대한. 연구," Journal of the Ergonomics Society of Korea, Vol. 17, No.1, pp. 
27-39, 1998.

[6] 최종원, 오경환, "비지도 학습 방법을 적용한 모듈화 신경망 기반의 패턴 분류기 설계," 한국 인지과학회 논문지 , Vol. 10, No.1, pp. 13-24, 1997.

[7] Hon Keung Kwan, Yaling Cai, “A Fyzzy Neural Network and its Application to Pattern Recognition," IEEE Transactions on Fuzzy Systems, Vol. 2, No.3,

[8] Monastra VJ. Electroencephalographic biofeedback (neurotherapy) as a treatment for attention deficit hyperactivity disorder: rationale and empirical foundation. Child Adolesc Psychiatr Clin N Am. 2005 Jan;14(1):55-82, vi. Review.

[9] Hirshberg LM, Chiu S, Frazier JA. Emerging brain-based interventions for children and adolescents: overview and clinical perspective. Child Adolesc Psychiatr Clin N Am. 2005 Jan;14(1):1-19, v. Review.

[10] Schenk S, Lamm K, Gundel H, Ladwig KH. Neurofeedback-based EEG alpha and EEG beta training. Effectiveness in patients with chronically decompensated tinnitus. HNO. 2005 Jan;53(1):29-37. German.

[11] Kropotov JD, Grin-Yatsenko VA, Ponomarev VA, Chutko LS, Yakovenko EA, Nikishena IS. ERPs correlates of EEG relative beta training in $\mathrm{ADHD}$ children. Int J Psychophysiol. 2005 Jan;55(1):23-34.

[12] Fernandez T, Herrera W, Harmony $T$, iaz-Comas L, Santiago E, Sanchez L, Bosch 'J, Fernandez-Bouzas A, Otero G, Ricardo-Garcell J, Barraza C, Aubert E, Galan L, Valdes R. EEG and behavioral changes following neurofeedback treatment in learning disabled children. Clin Electroencephalogr. 2003 Jul;34(3):145-52.

\section{저 자 소 개}

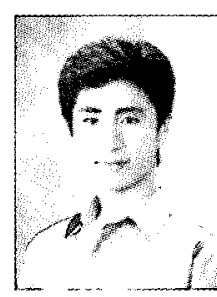

이동훈(Dong-Hoon Lee)

2005년 : 순천대학교 전기제어과 공학사

2005년 현재 : 중앙대학교 대학원

전자전기공학부석사과정

관심분야 : 감정인식, 로보틱스, 이동로봇, 홈 네트워크

Phone : $+82-2-820-5319$

E-mail : sky52929@wm.cau.ac.kr

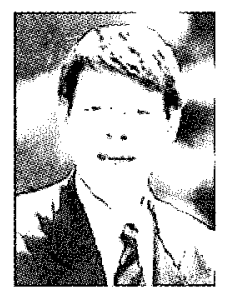

심귀보(Kwee-Bo Sim)

1990년 : The University of Tokyo 전자공학과 공학박사

1991년 현재 : 중앙대학교

전자전기공학부 교수

[제16권 4호(2006년 4월호) 참조]

2006년 현재 : 한국퍼지 및 지능시스템학회 회장

E-mail : kbsim@cau.ac.kr 